\title{
ANALYSIS OF THE CURRENT STATE OF RESEARCHES OF THE DEPOSITION OF ASPHALT-RESINOUS SUBSTANCES, PARAFFIN, AND MODELING METHODS. REVIEW PART II: WAX DEPOSITION
}

\author{
M.R.Manafov, G.S.Aliyev, A.I.Rustamova, V.I.Kerimli \\ M.Nagiyev Institute of Catalysis and Inorganic Chemistry, NAS of Azerbaijan \\ mmanafov@gmail.com
}

Received 14.12.2020

Accepted 28.01.2021

\begin{abstract}
The mechanism of paraffin formation in transport pipes is briefly discussed. A kinetic model of the formation and wax deposition from oil is proposed. Comparison of the model with the available experimental data gave satisfactory results. The review considers software tools for modeling the wax deposition process. It is noted that the simulation results are not always applicable to real field cases. For a more reliable interpretation, the scaling effect must be taken into account. In the work various technologies for wax removal are considered.
\end{abstract}

Keywords: shearing dispersion; shearing energy; wax deposition, wax appearance temperature (WAT), rheological properties, chemical inhibitors.

doi

\section{Introduction}

Wax formation in subsea pipelines is a serious problem in the oil industry, which requires huge economic costs. Many researchers have reported that approximately $85 \%$ of the world's oils experience problems due to the formation of wax [1]. Deposition of wax from petroleum fluids during production and transportation can cause many problems [2]. Ordinary paraffinic oil is unrefined and, in addition to paraffin, contains other heavy organic substances such as asphaltenes, resins, etc. [3]. The practice of oil production in the fields shows that the main areas of accumulation of asphaltene-resin-paraffin deposits (ARPD) are well pumps, lifting strings in wells, flow lines from wells, reservoirs of field gathering points [4].

Usually, in practice, two methods are used for calculating the crystallization of ARPD, based on which there is: the diffusion mechanism [5] and crystallization from a supersaturated solution. The diffusion mechanism is based on a three-stage scheme: 1) paraffin begins to crystallize, forming a crystal core when the temperature is below WAT; 2) crystal growth and 3) deposition on a cooled wall, the driving force is - the temperature difference between the equipment wall and the fluid flow [6]. This mechanism is often used for calculations in tubing and underground equipment.

At crystallization from a supersaturated solution, which is based on the theory of thermodynamic equilibrium of phases, the driving force is the solution saturation. It is assumed that there is a local thermodynamic equilibrium of the phases, the equilibrium in the phases is established instantly, and the effect of the diffusion component is determined by the Schmidt number (for oil Sc>1000). Often there are assumptions in this mechanism: paraffin crystals are not transferred in a pore medium, and if the concentration gradient is not taken into account, then there is no need to consider the process of formation of supramolecular structures. But in tasks related to pipe transport and waxing of field equipment, this process should be taken into account.

Wax deposition occurs when the oil temperature is lower than the wax appearance temperature (WAT) and there is a temperature gradient between the crude oil and the colder deposition surface. The wax deposition is a function of various factors including flow rate, oil and surface temperature, composition, thermal history, pressure etc. 
Many researchers have carried out several experimental studies of the mechanisms that affect wax deposition. Unfortunately, the results of laboratory and field studies often deviate markedly. Venkatesan and Creek [7] recommend revising existing laboratory methods to solve this problem.

The authors of the works $[8,9]$ to describe the process of wax deposition by the proposed bellow following stages:

1. Gelation of the waxy oil (formation of incipient gel layer) on the cold surface.

2. Diffusion of waxes (hydrocarbon with carbon numbers greater than the critical number) towards the gel layer from the bulk oil.

3. Internal diffusion of these molecules through the trapped oil.

4. Precipitation of these molecules in the deposit.

5. Counter-diffusion of de-waxed oil (hydrocarbon with carbon numbers lower than the critical carbon number) out of the gel layer.

The paraffin present in petroleum oils is mainly composed of paraffinic hydrocarbons $\left(\mathrm{C}_{18}-\mathrm{C}_{36}\right)$, known as paraffin wax, and naphthenic hydrocarbons $\left(\mathrm{C}_{30}-\mathrm{C}_{60}\right)$. These molecules can be straight or branched hydrocarbon chains and can contain some cyclic and/or aromatic hydrocarbons. The hydrocarbon compo- nents of the wax can exist in different phases, be it gas, liquid or solid, depending on their temperature and pressure. When the wax freezes, it forms crystals. Paraffin wax crystals are known as macrocrystalline wax (Figure 1a) [10]). Those one formed from naphthenes are known as microcrystalline wax (Figure 1b). The set of normal paraffins with 16 or more carbon atoms $\left(\geq \mathrm{C}_{16}\right)$ which form solid substances crystalline at the turbidity temperature is known as wax.

The main factor affecting the intensity of the crystallization of paraffin is a decrease in temperature, which, in turn, is determined by the degassing process (heat absorption due to degassing and a decrease in temperature due to the Joule-Thomson effect). Thus, the main "driving effect" of reducing well productivity is the degassing process [11].

It is known that the dissolving capacity of oil as regards to paraffin decreases with decrease in temperature and degassing of oil. In this case, the temperature factor prevails [2]. The rate of heat transfer depends on the temperature difference between the fluid and the surrounding rocks at a certain depth, as well as the thermal conductivity of the annular space between the riser pipes and the production string.

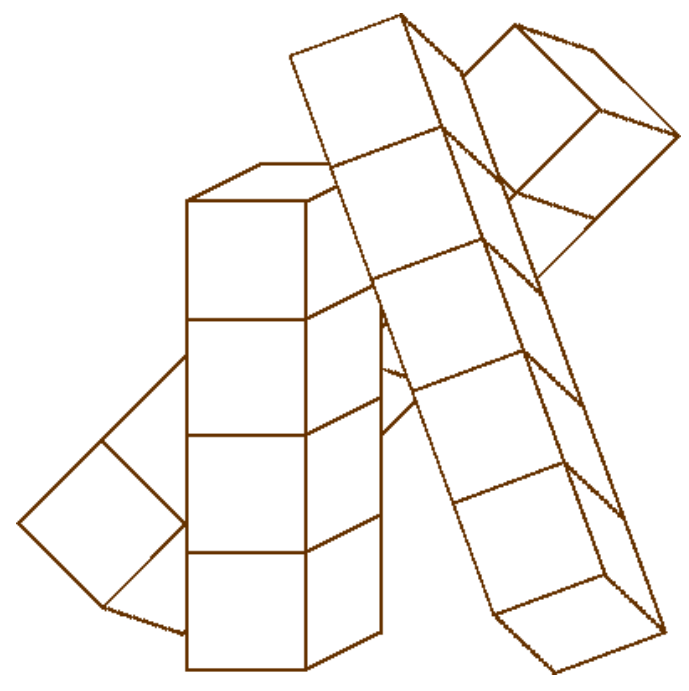

a)

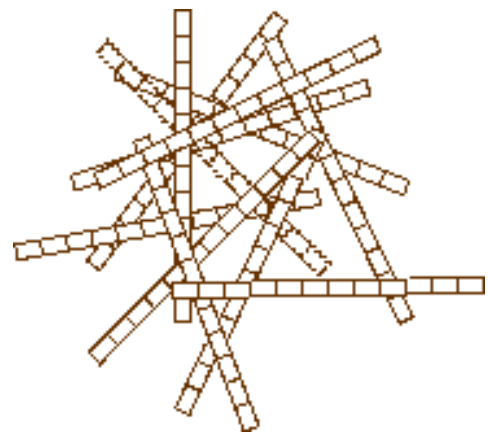

b)

Fig. 1. $a$-macrocrystalline [10]; $b$-microcrystalline [10]. 
With an increase in the speed of oil movement, the intensity of deposits first increases, that is explained by an increase in flow turbulence and, consequently, an increase in the frequency of formation and separation of bubbles from the pipe surface, floating suspended particles of paraffin and asphalt-resinous substances [2]. Also, the moving stream tears off part of the sediments from the pipes walls, which can explain the sharp decrease in sediments in the interval $0-50 \mathrm{~m}$ from the mouth. The moving stream, having high flow velocities, is more resistant to cooling, which also slows down the formation of ARPD.

The roughness of the walls and the presence of solid impurities in the system also contribute to the release of paraffin from the oil into the solid phase.

In addition to these main factors, the intensity of pipelines waxing during the transportation of watered well products can be influenced by the water cut of the product [12] and the $\mathrm{pH}$ of formation waters [2].

Studies $[6,13]$ have shown that the most probable mechanism of paraffin formation is the crystallization mechanism, i.e. in conditions when the gas-liquid flow can transport heavy components, the formation and further build-up of paraffin deposits occur due to the growth of crystals directly on the surface of underground equipment. Wax formation begins where oil comes in contact with the cold walls of underground equipment.

The necessary conditions for the formation of paraffin deposits are [14]:

- the presence of high-molecular hydrocarbon compounds in oil-primarily paraffin;

- reduction of reservoir pressure to saturation pressure;

- reducing the flow temperature to values at which the solid phase is released from oil;

- the presence of a substrate with a low temperature, on which high-molecular hydrocarbons crystallize with sufficiently strong adhesion to the surface, excluding the possibility of tearing off deposits by a flow of a gas-liquid mixture or oil at a given technological mode.
Many other factors contribute to or prevent the intensive formation of paraffin deposits. The most significant of them can be attributed to the oil flow rate, the process of gas release when the pressure in the pipeline decreases, the presence of mechanical impurities, which are active crystallization centers, the condition of the equipment surface, the water cut of the well production etc.

Various experimental techniques such as flow loop, cold finger, and rotating cylinder are used to study the wax deposition phenomenon [15].

Summarizing the above, it can be concluded that the technical problems associated with wax deposition include:

- Decreased permeability and formation damage, around the wellbore and its surroundings

- Reduced bore and possible clogging of production lines and flow channels

- Changes in formation fluid composition and fluid rheology due to phase separation as paraffin wax settle.

- The additional load on pumping equipment due to increased pressure drop due to rheological changes during wax crystallization.

- Limiting effect on the performance of the entire production system.

\section{Approaches to mathematical model- ing and mechanisms of the wax deposi- tion process}

The mathematical modeling approach is widely used to predict and monitor wax deposition, either directly numerically or using software that has an internal mathematical model.

Wax deposition models are designed with assumptions and parameter choices in mind.

Four wax deposition mechanisms need to be considered when simulating wax deposition growth in pipelines, namely molecular diffusion, shear dispersion, gravity deposition, and Brownian diffusion [16]. Molecular diffusion, which can be described in terms of mass transfer and energy balance, is universally recognized as dominant, while other mechanisms mentioned have been identified as having little effect on this phenomenon. 
Some researchers have proposed the inclusion of a shear dispersion mechanism to analyze the wax deposition behavior, especially in laminar flow. However, other researchers reported based on some experiments that this mechanism plays an insignificant role in the deposition of wax [17]. The gravity settling mechanism assumes that wax crystals will settle to the bottom of pipelines because the crystals are denser than oil. However, this effect appears to be insignificant, since experimental studies comparing vertical and horizontal liquid flows did not reveal differences in the amount of deposited wax [18]. Once the wax crystals are deposited and suspended in the oil, the wax crystals will behave according to the rules of Brownian motion. Since the effect of motion is likely to transport crystals to areas with a lower wax concentration, this can influence the wax deposition behavior. However, its effect is usually considered minimal and is usually neglected when simulating the overall deposition mechanism. Consequently, the last three mechanisms are not widely accepted, especially for computer simulation procedures [19-21].

Various studies have shown that molecular diffusion is seen as the dominant mechanism in the wax deposition process [22,23], and shear stress is significant only when the oil temperature is much lower than WAT and the wax concentration in the oil is high [24].

In turn, the paraffin deposition process due to molecular diffusion can be divided into the following five stages [25]:

(1) precipitation of dissolved paraffin molecules and formation of a layer of deposits on the surface of the pipe wall;

(2) the formation of a radial gradient of the concentration of dissolved paraffin components, which leads to the diffusion of paraffin molecules from the bulk of the oil to the wall;

(3) the deposition of paraffin components on the surface of the existing sediment, that contributes to an increase in its thickness;

(4) internal diffusion of paraffin molecules inside the sediment, that leads to an increase in the proportion of solid paraffin in the sediment;

(5) counter-diffusion of dewaxed oil from the sediment.

\section{Wax deposition modeling software}

Various commercial instruments have been developed to correctly predict and describe the wax deposition phenomenon.

The literature $[19,26]$ widely describes the use of commercial codes OLGA v2016.1 (OLGA Dynamic Multiphase Flow Simulator, Schlumberger, Houston, TX, USA) and Leda Flow v2.1 (Kongsberg Gruppen ASA Kirkegårdsveien 45 NO-3616 Kongsberg Norway), in modeling the process of wax deposition in pipelines, in a multiphase flow.

The most commonly used thermohydraulic transient simulation software for multiphase flow in pipelines used in an oil and gas field is called OLGA.

Leda Flow from Kongsberg. This commercial software is another unsteady multiphase flow simulator which, like OLGA, includes a module to simulate wax deposition. This model was developed by the University of Michigan Porous Media Research Group.

In this row, the wax deposition model implemented in FloWax (from KBC) should be noted. It is very similar to the previous one but implements other thermodynamics of paraffin.

Schlumberger OLGA is a standard transient modeling tool for multiphase oil production [27] and implements three mathematical models for modeling wax deposition in pipelines: RRR (Rygg, Rydahl, and Renningsen) model, Matzain model, and Thermal analogy model. All of these wax deposition models follow the same formula for estimating wax deposition thickness. What changes in each model is the calculation of the parameters, which depends on the experimental data.

1. Model RRR is a multiphase wax deposition model that predicts wax deposition in wells and pipelines and is a combination of functions, each describing a different phenomenon [28]. These are the pressure drop, energy inputs, and outputs, the behavior of paraffin with changes in pressure and temperature, the mechanism of paraffin transfer, etc. This is a semistationary model because the wax build-up is a slower process than pipeline flow disturbances and this does not apply to laminar flow [29]. 
Molecular diffusion and shear dispersion effect are believed to be the only mechanisms responsible for wax deposition. The volumetric rate of wax deposition by the molecular diffusion method for the paraffin-forming component $i$ is calculated by the formula (1):

$$
\mathrm{Vol}_{\mathrm{wax}}^{\mathrm{diff}}=\sum_{i=1}^{N_{\mathrm{wax}}} \frac{D_{\mathrm{wo}, i}\left(C_{\mathrm{wb}, i}-C_{\mathrm{wc}, i}\right) S_{\mathrm{wet}} M_{\mathrm{wax}, i}}{\delta_{\text {lam }} \rho_{\mathrm{wax}, i}} 2 \pi \mathrm{r}_{\mathrm{s}} L,
$$

where $N_{\text {wax }}$ - is the number of paraffinic components, $D_{\mathrm{wo}, i}-$ is the diffusion coefficient calculated using the Hayduk-Minhas correlation [30], $C_{\mathrm{w} b, i}$ and $C_{\mathrm{ws}, i}$ - are the molar concentrations of the paraffinic component $i$ dissolved in oil and on the surface of the deposit, respectively, $S_{\text {wet }}$-wetted part of the circle, $M_{\text {wax }, i}-$ is the molar mass of the paraffin component $i, \delta_{\mathrm{lam}}-$ is the thickness of the laminar sublayer, $\rho_{\mathrm{wax}, i}-$ is the density of the paraffin component $i, r_{s}-$ is the current inner radius of the pipe, $L-$ is the length of the pipe section.

The RRR model does not take into account the removal of wax from the wall at high speed flows, due to shear stress, however, it implements the model of dissolution of wax deposited on the pipe wall. The model calculates the change in the concentration of dissolved paraffin by temperature, $\mathrm{d} C \mathrm{w} / \mathrm{d} T$, at an appropriate WAT for the section pressure. The concentration of dissolved wax at the surface of the deposit is controlled when the surface temperature of the deposit is higher than the wax dissolution temperature (WDT) given in equation (2):

$$
W D T=W A T+\Delta T_{\text {dissolution }}
$$

2. The Matzain model is a semi-empirical model, which is a broader approach to wax deposition as it includes molecular diffusion, shear dispersion, and shear delamination, which includes a wax recovery mechanism known as shear removal, along with molecular diffusion and shear dispersion to model wax deposition [31]. The model is based on the diffusion coefficient as per Wilke and Chang. In this model, a shear variance is considered minor compared to the RRR model. The wax accumulation rate is calculated by an empirical modification of Fick's law:

$$
\frac{\mathrm{d} \delta}{\mathrm{d} t}=\frac{\Pi_{1}}{1+\Pi_{2}} D_{\mathrm{wo}}\left[\frac{\mathrm{d} C_{w}}{\mathrm{~d} T} \frac{\mathrm{d} T}{\mathrm{~d} r}\right],
$$

where $\delta-$ is the thickness of the paraffin layer deposited on the wall, $D_{\text {wo }}-$ is the diffusion coefficient calculated using the Wilke-Chang correlation, $C_{w}$ is the concentration of paraffin in the solution (wt\%), $r$-is the radial distance of the pipe $(\mathrm{m}), \mathrm{T}$ is the liquid temperature $\left({ }^{0} \mathrm{C}\right)$.

The coefficient $\Pi_{1}$ is related to the effect of porosity on the degree of wax deposition, and $\Pi_{2}$ is related to shear.

3. Thermal analogy is third paraffin deposition model implemented in OLGA. The thermal analogy calculates the mass transfer rate of wax using the heat transfer analogy. The heat transfer rate is defined as:

$$
\dot{Q}=h\left(T_{w b}-T_{w s}\right),
$$

where $h-$ is the heat transfer coefficient. Similarly, the mass transfer rate of component $i$ can be expressed as:

$$
\dot{M}_{i}=m_{i}\left(C_{w b, i}-C_{w s, i}\right),
$$

where $m_{i}-$ is the mass transfer coefficient. The heat transfer coefficient is calculated using the Nusselt number $(\mathrm{Nu})$, which is a function of the Reynolds numbers (NRe) and Prandtl numbers (NPr):

$$
N_{\mathrm{Nu}}=f\left(N_{\mathrm{Re}}, N_{\mathrm{Pr}}\right)
$$

Note that the thermal analogy model, like the RRR, includes the effect of shear deposition and, like Matzain, takes into account the shear phenomenon [21].

4. University of Michigan model (LedaFlow's wax) implemented in LedaFlow code, describes a simplified one-dimensional wax deposition model and simulates two processes:

- crystallization of paraffin with the formation of a paraffin suspension, in which the paraffin particles are suspended (suspended) in the oil phase;

- wax deposition on the pipe wall

Radial diffusion of dissolved paraffin molecules causes the accumulation of wax deposits: the concentration difference $\left(C_{w b}-C_{w s}\right)$ is the driving force of mass transfer.

The deposition rate constant $\left(k_{r}\right)$ is obtained using the equation

$$
k_{r}=k_{d} A_{p} \rho_{n}=\left(\frac{S h_{p} \cdot D_{w o}}{d_{p}}\right) A_{p} \rho_{n},
$$


where $k_{d}$ - is the coefficient of mass transfer from the volume to the surface of an individual nucleus, $A_{p}$ - is the surface area of the nucleus, and $\rho_{n}-$ is the density of paraffin cores, $S h_{p}$ is the Schmidt number, $d_{p}-$ is the critical size of the nucleus. The LedaFlow model also supports wax melting, which increases the amount of wax dissolved in the oil. LedaFlow showed two main limitations: it does not account for the effect of pressure on the WAT, which determines the onset of wax deposition, and does not simulate flow restriction due to wax buildup, thus failing to reproduce the inlet pressure increment.

5. FloWax Model (from KBC) is a fully compositional wax deposition model which combines an accurate model for wax deposition thermodynamics, a diffusion wax deposition model based on heat and mass transfer analogy, and a shear action on wax deposition caused by the turbulence of the flowing liquid. Paraffin is viewed as a fully compositional distribution of $n$-paraffins. A rigorous solution to the sediment growth rate can be obtained by solving the coupled equations of momentum, energy, and mass transfer based on the boundary layer conditions by finite element methods.

Unlike the University of Michigan model, FloWax implements shear ablation modeling and wax deposition thermodynamics. The Coutinho paraffin model [32] is implemented in FloWax by KBC. Model by Coutinho et al. par- affin wax is based on a more robust thermodynamic principle of wax phase behavior, in contrast to other models relying heavily on predictive validation by measurements such as WAT. The key factors of this paraffin model are the behavior of the n-paraffin solution in the oil phase, the thermodynamic properties of nparaffin melting, and the thermodynamics of solid solutions of $n$-paraffins, the paraffin phase. The model is available in two versions: Wilson and Uniquac (Universal Quasi-chemical Theory) wax models. The Wilson model is easier to apply since it considers the paraffin phase as a single solid solution of $n$-paraffins. The Uniquac model is more realistic as it predicts that the paraffinic phase decomposes into several coexisting solid solution phases [19]. The characterization of the fluid is obtained by storing all the details of the distribution of nparaffins measured by HTGC (high-temperature gas chromatography). The pseudo-components of N-paraffins with a carbon number of 20 or more are the only paraffin-forming agents.

All wax deposition models follow the same formula for estimating wax deposition thickness. What changes in each model is the calculation of the parameters, which depends on the experimental data. in Table.

A brief description of the model is given

A brief description of the model used by the software

\begin{tabular}{|c|c|l|c|}
\hline Model & Software & \multicolumn{1}{c|}{ Description } & Reference \\
\hline RRR & $\begin{array}{c}\text { OLGA } \\
\text { Schlumberger }\end{array}$ & $\begin{array}{l}\text { The multiphase flow wax deposition model, which predicts wax } \\
\text { deposition in wells as well as pipelines, is a combination of func- } \\
\text { tions, each of which describes a different phenomenon. Semi- } \\
\text { stationary model. }\end{array}$ & {$[25,27-29]$} \\
\hline Matzain & $\begin{array}{l}\text { OLGA }^{\mathrm{TM}} \text { from } \\
\text { Schlumberger }\end{array}$ & $\begin{array}{l}\text { Semi-empirical model taking into account shear removal, molecular } \\
\text { diffusion, and dispersion shear to predict wax deposition. }\end{array}$ & {$[25,27,31]$} \\
\hline $\begin{array}{c}\text { Heat } \\
\text { analogy }\end{array}$ & $\begin{array}{l}\text { OLGA }^{\mathrm{TM}} \text { from } \\
\text { Schlumberger }\end{array}$ & $\begin{array}{l}\text { Calculates the mass transfer rate of wax using the heat transfer } \\
\text { analogy. Takes into account the phenomenon of shear and includes } \\
\text { the effect of shear deposition. }\end{array}$ & {$[25,27,19]$} \\
\hline $\begin{array}{c}\text { University } \\
\text { of Mich- } \\
\text { iqan Model }\end{array}$ & $\begin{array}{c}\text { LedaFlow } \\
\text { from Kongsberg }\end{array}$ & $\begin{array}{l}\text { Simulates wax crystallization and wax deposition on the pipe wall. } \\
\text { It has two main limitations: it does not account for the effect of } \\
\text { pressure on WAT, which determines the onset of wax settling, and } \\
\text { it does not simulate flow restriction due to wax buildup, thus failing } \\
\text { to reproduce the inlet pressure increment. }\end{array}$ & {$[19,25]$} \\
\hline FloWax & $\begin{array}{l}\text { FloWax } \\
\text { from KBC }\end{array}$ & $\begin{array}{l}\text { Complete Composite Wax Deposition Model which takes into } \\
\text { account thermodynamic wax deposition, wax diffusion based on the } \\
\text { heat and mass transfer analogy, and the shear effect. }\end{array}$ & {$[26]$} \\
\hline
\end{tabular}




\section{The methods of prevention of paraf- fin deposits}

The problem of wax build-up is complex because many factors affect wax deposition, such as wax concentration in crude oil, ambient temperature, wax appearance temperature, pressure drop, oil viscosity, and oil volume temperature. The main problems associated with wax deposition in crude oil appear in oil transport lines. Sudden clogging of lines by wax deposits affects flow assurance and may lead to immediate maintenance and repair actions. The deposited paraffin layer can be observed as three sublayers: the uppermost layer is more granular and softer, the lower layer has a strong bond with the pipe wall and is considered a tightly adjacent layer, and the sandwiched layer between the upper and lower parts has mechanical impurities and high wax content. The process of diffusion and counter-diffusion resulting in the hardening of the precipitate, increasing the size of the precipitate, and increasing the amount of wax in the layer of deposits is called aging (hardening), the second stage of wax deposition. Increasing the size of the layer of wax deposits, reducing the effective crosssection of the flow, disturbing the operating regime of the flow. The severe sediment problem causes great economic damage to oil companies, so various methods have been developed to prevent and eliminate sediment problems, and further research is ongoing to find more effective methods to improve the situation. In the practice of oil production and transportation, various methods are widely used both to prevent the formation of ARPD and to remove already formed deposits on the internal surfaces of oilfield equipment. When choosing a method for the prevention or prophylactic removal of ARPD deposits, it should be borne in mind that the effectiveness of the method depends on the method of extraction, as well as on the composition and properties of the extracted product.

\section{Chemical methods for removing wax} deposits. The essence of chemical methods for the removal of ARPD is their preliminary destruction or dissolution followed by removal.
For these purposes, the following are used: organic solvents with a high dissolving power of not only solid hydrocarbons, but also asphaltresinous substances; aqueous solutions of surfactants, which, upon contact with paraffin deposits, penetrate their thickness and, dispersing the resin-paraffin mass, reduce their strength up to destruction [33].

One of the most effective ways to eliminate wax deposits is to use solvents, the volume of which is determined by the amount and solubility of the wax in the available solvent. Aliphatic and aromatic solvents are the main groups of solvents used in oil fields. Among individual solvents, aromatic compounds such as benzene, toluene, xylenes, ethylbenzene, chlorobenzene are most effective. Mixing xylene or toluene with an aliphatic solvent has been shown to increase wax removal efficiency. However, many of these solvents are not environmentally friendly.

Chemical methods mainly use chemical inhibitors, and these are added to the oil to reduce wax build-up. These chemical paraffin inhibitors can be classified into three: detergents, dispersants, and wax crystal modifiers. Surface activators and dispersants that keep the wax particles suspended and dispersed so that the reducing wax particles adhere to each other or the pipe walls or any solid surface. Surface activating agents also modify the solid surface of the pipe, reducing shear and interaction of wax particles on the wall of the transport line. Other types of surfactants also alter solubility by dissolving the core. Solvents and solutions of surfactant compositions are more effective at elevated temperatures. In practice, chemical methods for removing paraffin deposits are often used in combination with thermal and mechanical methods. In this case, the greatest technological and economic effect is achieved as a result of the significant acceleration of the process and completeness of the removal of ARPD. The thermochemical packaging method uses the heat from an exothermic reaction to melt wax deposits in a well or underwater flow lines. The big disadvantage of this technology is that only areas close to the point of introduction of the chemical could be 
treated because the exothermic reaction would have been completed before the chemicals reached the remote areas. Therefore, technologies are being developed which can control the onset of an exothermic reaction and the release of heat after the estimated time.

2. Microbial methods against wax deposition is not common; however, it is effective in several field trials. The action of the bacterial culture produces a biosurfactant, which is reported to contribute as a paraffin inhibitor. Bacterial strains such as Actinomyces spp. Showed the degradation of heavy chain hydrocarbons $\left(\mathrm{C}_{15}\right.$ to $\left.\mathrm{C}_{20}\right)$ when processing crude oil samples.

3. Mechanical methods. The problem of wax deposition in the well can be solved by mechanical removal. This method involves using pigs directly, using them in the pipe, and using a "pig" device inside the pipe. Scrapers are used to clean the pipe wall and remove wax even while the well is running. However, if the scraping mechanism encounters high resistance, it can become stuck inside the pipeline and cause a serious malfunction [34]. Mechanical wax removal is considered the oldest method used in the industry. Existing methods of purely mechanical action do not give good results in pipelines, since conventional flow rates do not provide the necessary forces for the action of pigs on dense layers of ARPD.

4. Thermal methods. The wax deposition is highly temperature-dependent; therefore they can be very effective in both preventing and eliminating wax deposition problems.

Wax deposits are removed thermally by pouring hot oil into the pipe to melt the wax deposits.

Thermal methods are mainly used to maintain the temperature of the environment or to of the crude oil to reduce wax build-up. Some of the common methods are hot lubrication or hot watering, cold flow, and surface coating.

Using hot oil or hot water (temperature in the range of $65-150^{\circ} \mathrm{C}$ ), pumped into the transport line, the applied paraffin is melted. By using solid resin particles that have a melting point greater than the WAT in the oil to aid the flow of the slurry, wax deposition towards the wall is prevented [33].

\section{Physical methods of dealing with} ARPD involve exposure to ultrasonic and vibration vibrations; electric, magnetic and electromagnetic fields, as well as coating hard surfaces with enamels, glass, bakelite varnish. Vibration and ultrasonic influences make it possible to create vibrations in the area of ARPD formation, which, when exposed to the crystals, promote their movement, and as a result, prevent the deposition of the crystals formed on the inner surfaces of the equipment. The impact of magnetic fields to prevent the formation of ARPD is not widespread, due to the low efficiency of the action.

Ultrasonic treatment of oils is relevant for use for high-viscosity oils. According to various sources, the use of ultrasonic treatment can reduce the viscosity up to 1.8 times, including this affects the rheological properties, while the chemical composition of oil remains unchanged.

6. Chemical-mechanical methods implies a combined mechanical and physicochemical effect of aqueous solutions of surface-active substances (SAS) on ARPD and the surface to be cleaned. These methods are used for jet, circulation, steam-water jet, and submersible cleaning of pipelines, tanks, and parts of oil field equipment from the formed ARPD.

\section{Diffusion kinetics of paraffin crys- tallization}

Wax crystallization begins with nucleation, where in oil, solid asphaltene particles with a size of $1 \mathrm{~nm}$ or a solid phase can be used as nuclei. In [35], an empirical model is used to describe the processes of crystallization and wax deposition, in contrast to which a diffusion model corresponding to the diffusion kinetics of the formation and deposition of waxes from oil is proposed below. The crystallization process is a diffusion process, and the condition is satisfied on the surface of the nuclei [36]

$$
-\left.D \frac{\partial C}{\partial r}\right|_{r=R}=\beta_{L}\left(C-C^{*}\right) \text {. }
$$


Assuming that $\mathrm{d} r=V \mathrm{~d} t$ the equation of kinetics crystallization of paraffins can be represented as

$$
\frac{\mathrm{d} C}{\mathrm{~d} t}=-K_{p}\left(C-C^{*}\right),
$$

here $K_{p}=V \beta_{L} / D$ is the crystallization rate constant, which also depends on temperature $T, C$ - is the concentration of paraffin in the volume of the boundary layer, $C^{*}-$ is the equilibrium concentration of paraffin in the liquid and solid phases, depending on temperature, and $\beta_{\mathrm{L}}-$ is the mass transfer coefficient, $D-$ is coefficient of molecular diffusion. The solution to this equation can be represented as

$$
C(t)=C^{*}\left[1-\exp \left(-\int_{0}^{t} K_{p} \mathrm{~d} t\right)\right] .
$$

Practical calculations show that this equation can be written in the form

$$
C(t)=C^{*}(T)\left[1-\exp \left(-\beta t^{n}\right)\right] \text {. }
$$

As follows from equation (11), at $t \rightarrow \infty$, we have, $C(t) \rightarrow C_{\infty}$, where $C_{\infty}$ is the limiting the concentration of paraffins on the surface of the layer, corresponding to equilibrium and the maximum thickness of the layer of paraffins on the surface.

If the maximum thickness of the deposited paraffin layer is equal to the pipe radius, then there is a complete blockage of the pipe section. Using the experimental data [35], it is possible to estimate the coefficients $\beta=0.05, C^{*}(\Delta T)=1.2 \cdot 10^{9} \exp (-7473.5 / \Delta T)$ (where $\Delta T$ is the absolute temperature difference between the surface temperature and the crystallization temperature). Practical calculations show that in the indicated limit of temperature change, the exponent changes insignificantly $n=0.65$. The results of experimental studies [35] and calculated values by formula (11) for different temperatures are shown in Figure 2.

As follows from Figure 1, the concentration of paraffins over time tends to the established state.

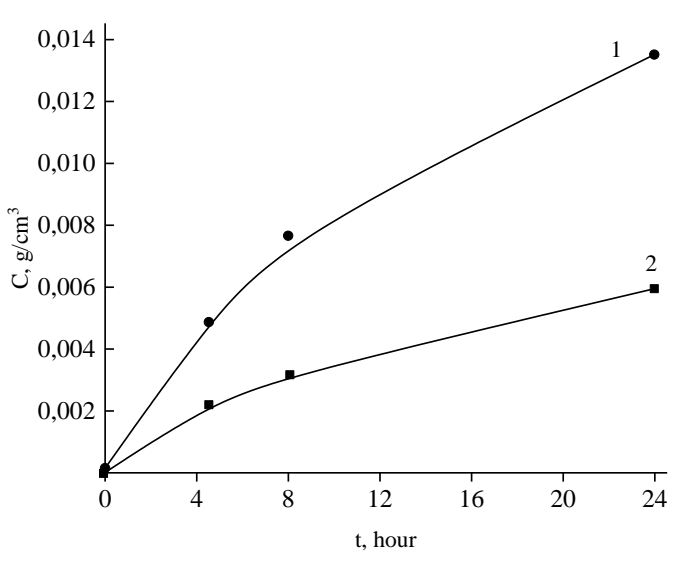

Fig. 2. Crystallization of paraffins from oil at temperatures $\Delta T$ equal to: $1-37^{0} \mathrm{C}, 2-27^{0} \mathrm{C}$.

\section{Results and discussion}

The presented diffusion model of crystallization kinetics (11) is of a migrationdiffusion nature, where both the diffusion of paraffin from the liquid phase to the solid and the diffusion transfer of paraffin particles to the surface play an important role. If a decrease in temperature in the flow core is observed over time, then the formed paraffin particles together with asphaltene particles have a significant effect on the structure formation in the flow and thereby change the rheological properties of oil [37]. Computational modeling can be a powerful tool for predicting and interpreting wax deposition phenomena after validation with available experimental data. Most laboratory experiments are based on a single-phase flow, which often gives deviations from multiphase flow cases. Simulation results are not always applicable to real field cases. For a more reliable interpretation, the scaling effect must be taken into account. Current research needs to focus on more complex environments. One way to solve this problem is to test these models with an additional set of field data.

\section{Acknowledgments}

This work was supported by the Science Foundation of «SOCAR» under the grant project 04LR - AMEA (10/09/2019) at the 
M.Nagiyev Institute of Catalysis and Inorganic Chemistry.

The authors express their gratitude to Professor Kelbaliev G.I. (M.Nagiev Institute of Catalysis and Inorganic Chemistry) for valuable critical comments and recommendations.

\section{References}

1. Thota S.T., Onyeanuna C.C. Mitigation of Wax in Oil Pipelines. Int. J. Eng. Res. Rev. 2016. V. 4. No 4. P. 39-47.

2. Park S.J. and Mansoori G.A. Aggregation and Deposition of Heavy Organics in Petroleum Crudes. Int. J. Energy Sources. 1988. V. 10. P. 109-125.

3. Ali Mansoori G., Lindsey Barnes H., Glenn M. Webster. Petroleum Waxes, Manual 37 - Fuels and Lubricants Handbook: Technology, Properties, Performance, and Testing, ASTM Manual Series: MNL37WCD. 2003. Chapter 19. P. 525-556.

4. Salah Yaseen, Ali Mansoori G. Microscopic details of asphaltenes aggregation onset during waterflooding. Petroleum Sci. and Technology J. 2019. V. 37. No 5. P. 573-580.

5. Huang Z., Zheng S., Fogler H.S. Wax Deposition: Experimental Characterizations. Theoretical Modeling, and Field Practices; CRC Press: Boca Raton, FL, USA; London, UK. 2016.

6. Kuznetsov S.V. Investigation of thermophysical processes in the filtration of paraffinic oil to a horizontal well. Abstract dissertation for the degree of candidate of physical and mathematical sciences. Tyumen, 2016. 20 p.

7. Venkatesan R., Creek J.L. Wax deposition during production operations. OTC 18798. Offshore Technology Conference. April 30-May 3, Houston, Texas. 2007.

8. Hernandez O., Hensley H., Sarica C. Improvements in single-phase paraffin deposition modeling. SPE Annual Technical Conference and Exhibition, 5-8 October, Denver, Colorado, USA. 2003.

9. Improved Prediction of Wax Deposition in Subsea Crude-Oil Pipelines in Nigeria O. A. Adeyanju, Published 2016, Environmental Science.

10. Mansoori A. Paraffin/Wax and Waxy Crude Oil: The Role of Temperature on Heavy Organics Deposition from Petroleum Fluids. 2009. [Online].

11. Senra M.J. Assessing the role of polydispersity and cocrystallization on crystallizing $\mathrm{n}$-alkanes in $n$-alkane solutions. University of Michigan, Ph.D. Thesis. 2009.

12. Manafov M.R., Kelbaliev G.I. Analysis of the modern state of researches on deposition of asphalt-resin substances, paraffin and modeling methods. Azerb. Chem. J. 2020. No 2. P. 6-19.

13. Musakaev N.G. About the mathematical schemes describing the process of wax crystallization in oil-gas wells. Special Issue Proceedings of Int. Conf. RDAMM - 2001，2001. No 6. P. 2.

14. Volkova G.I., Loskutova Yu.V., Prozorova I.V., Berezina E.M. Preparation and transportation of problem oils (scientific and practical aspects). Tomsk: TSU Publishing House, 2015. V. 136. P. 9.

15. Mojtaba Mansourpoor, Reza Azin, Shahriar Osfouri. Experimental investigation of wax deposition from waxy oil mixtures. Appl. Petrochem. Res. 2019. No 9. P. 77-90.

16. Todi S. Experimental and Modeling Studies of Wax Deposition in Crude Oil Carrying Pipelines. Ph.D. Thesis, University of Utah, Salt Lake City, UT, USA. 2005.

17. Marwa M. El-Dalatony, Byong-Hun Jeon1, ElSayed Salama. Occurrence and Characterization of Paraffin Wax Formed in Developing Wells and Pipelines. Energies. 2019. No 12. P. 967.

18. Guo B., Song S., Ghalambor A. Chapter 15-Flow Assurance. In Offshore Pipelines, 2nd ed.; Gulf Professional Publishing: Boston, MA, USA, 2014. P. 179-231.

19. Leporini M., Terenzi A., Marchetti B. et al. Experiences in numerical simulation of wax deposition in oil and multiphase pipelines: Theory versus reality. J. Pet. Sci. Eng. 2019. V. 174. P. 997-1008, [Cross Ref].

20. Li S., Huang Q., Zhao D., Lv Z. Relation of heat and mass transfer in wax diffusion in an emulsion of water and waxy crude oil under static condition. Exp. Therm. Fluid Sci. 2018. V. 99. P. 1-12. [Cross Ref].

21. Zheng S., Saidoun M., Mateen K. Wax Deposition Modeling with Considerations of Non-Newtonian Fluid Characteristics. In Proceedings of the Offshore Technology Conference, Houston, TX, USA, 2-5 May, 2016. P. 18.

22. Lashkarbolooki M., Seyfaee A., Esmaeilzadeh F., Mowla D. Experimental investigation of wax deposition in Kermanshah crude oil through a monitored flow loop apparatus. Energy Fuels. 2010. V. 24. P. 1234-1241.

23. Venkatesan R. The deposition and rheology of organic gels. PhD Thesis, Dept. of Chemical Engineering, University of Michigan. 2004.

24. Burger E.D., Perkins T.K., Striegler J.H. Studies of wax deposition in the Trans Alaska pipeline. Soc Pet Eng. 1981. https ://doi. org/10.2118/8788-pa.

25. Giancarlo Giacchetta, Barbara Marchetti, Mariella Leporini et al. Pipeline wax deposition modeling: A sensitivity study on two commercial software Petroleum. 2019. No 5. P. 206-213.

26. Noville I., Naveira L. Comparison between Real Field Data and the Results of Wax Deposition Simulation, SPE Latin American and Caribbean Petroleum Eng. Conf., Mexico. 2012.

27. Schlumberger OLGA, User Manual, 2016. 
28. Rygg P.O. Rydahl B.A., Rønningsen K.H. Wax deposition in offshore pipeline systems. $1^{\text {st }}$ North American Conf. on Multiphase Technology. Banff, Canada. 1998.

29. Rosvold K. Wax deposition models. Master thesis, NTNU - Norges teknisknaturvitenskapelige universitet. 2008.

30. Hayduk W.B. Minhas, Correlations for prediction of molecular diffusivities in liquids. Can. J. Chem. Eng. 1982. V. 60. P. 295-299.

31. Aiyejina A., Chakrabarti D.P., Pilgrim A., Sastry M.K.S. Wax formation in oil pipelines: a critical review. Int. J. Multiphas. Flow. 2011. V. 37. No 7. P. 671-694.

32. Coutinho J.A., Edmonds B., Moorwood T. et al. Reliable wax predictions for flow assurance. Energy Fuels. 2006. V. 20. No 3. P. 1081-1088.

33. Kang P.-S., Lee D.-G., Lim J.-S. Status of Wax Mitigation Technologies in Offshore Oil Production.
Presented at the Twenty-Fourth International Ocean and Polar Engineering Conference, Busan, Korea, 15-20 June. 2014. ISOPE-I-14-285.

34. Al-Yaari M. Paraffin Wax Deposition: Mitigation \& Removal Techniques. Presented at the SPE Saudi Arabia Section Young Professionals Technical Symposium, Dhahran, Saudi Arabia, 14-16 March. 2011. SPE-155412-MS.

35. Markin A.N., Sukhoverov S.V. Study of the kinetics of paraffin release from oil. Bulletin of the FEB RAS. 2011. No 5. P. 66-71.

36. Kelbaliev G.I., Rasulov S.R. Hydrodynamics and mass transfer in dispersed media. S.-Pb: Khimizdat. 2014.

37. Kelbaliev G.I., Rasulov S.R., Rzayev A.G. Modeling of oil filtration in a porous medium and technology of liquid-phase extraction of asphalttenes. Theoret. Foundations of Chem. Eng. 2016. V. 50. No 6. P. 573-682.

\title{
АНАЛИЗ СОВРЕМЕННОГО СОСТОЯНИЯ ИССЛЕДОВАНИЙ ПРОЦЕССА ОСАЖДЕНИЯ АСФАЛЬТО-СМОЛИСТЫХ ВЕЩЕСТВ, ПАРАФИНОВ И МЕТОДОВ МОДЕЛИРОВАНИЯ ОБЗОР
ІІ ЧАСТЬ: ОСАЖДЕНИЕ ПАРАФИНОВ
}

\section{М.Р.Манафов, Г.С.Алиев, А.И.Рустамова, В.И.Керимли}

\begin{abstract}
Кратко обсужден механизм образования парафина в транспортных трубах. Предложена кинетическая модель процесса образования и отложения парафинов из нефти. Сравнение модели с имеющимися экспериментальными данными дало удовлетворительные результаты. В обзоре рассмотрены программные средства для моделирования процесса осаждения парафина. Отмечено, что результаты моделирования не всегда применимы для реальных полевых случаев. Для более надежной интерпретации необходимо учитывать эффект масштабирования. Рассмотрены различные технологии удаления парафина.
\end{abstract}

Ключевье слова: сдвиговая дисперсия, энергия сдвига, отложение парафина, температура появления парафина(WАT), реологические свойства, химические ингибиторы.

\section{NEFTDӘN ASFALTEN-QATRAN, PARAFINLORIN ÇÖKMӘSİ PROSESININ MÜASIR VəZIYYOTININ Və PROSESIN MODELLOŞDIRMOSI ÜSULLARININ ANALIZi ICMAL \\ II HISSSə: PARAFINLORIN ÇÖKMəSI}

\section{M.R.Manafov, Q.S.Đliyev, A.İ.Rüstəmova, V.İ.Kərimli}

İcmalda neftin nəqli borularında parafinin əmələ gəlməsi prosesi q1sa şəkildə müzakirə olunur. Neft borularında parafinin əmələ gəlməsi prosesinin və parafinin çökməsinin kinetik modeli təqdim olunmuşdur. Model üzrə hesablamaların mövcud təcrübi göstəricilərlə müqayisəsi, qənaətbəxş nəticələr vermişdir. İcmalda parafinin çökməsi prosesinin modelləşdirilməsində müasir zamanda istifadə olunan kompüter proqramlarına baxılmış, onların analizi verilmişdir. Qeyd olunmuşdur ki, real çöl şəraiti hallarında modelləşdirmə nəticələri, həmişə tətbiq oluna bilməz. Etibarlı nəticələrin alınması üçün miqyas effektini nəzərə almaq, əlavə təcrübə nəticələrindən istifadə etmək lazımdır. İşdə parafin çökməsinin qarşısını almaq və onu kənar etmək üçün istifadə olunan müxtəlif texnologiyalara baxılmış və analiz edilmişdir.

Açar sözlar: sürüşmə dispersiyası, sürüşmə enerjisi, parafinin çökməsi, parafinin əməlagalmə temperaturu, reoloji xassalar, kimyəvi inhibitorlar. 